\title{
PROFILE OF PHYTOCHEMISTRY AND ANTIOXIDANT ACTIVITY OF SORREL IN FUNCTION OF ORGANIC FERTILIZATION AND DENSITY OF PLANTIO
}

\author{
PERFIL DE FITOQUÍMICA E ATIVIDADE ANTIOXIDANTE DE AZEDINHA EM \\ FUNÇÃO DA ADUBAÇÃO ORGÂNICA E DENSIDADE DE PLANTIO
}

\section{Marina Portugal TORRES ${ }^{1}$, Lanamar de Almeida CARLOS ${ }^{2}$, Marinalva Woods PEDROSA ${ }^{3}$, Ana Paula Coelho Madeira SILVA ${ }^{4}$, Ernani Clarete da SILVA ${ }^{5}$, Leila de Castro Louback FERRAZ}

1. Engenheira Agrônoma, Mestre, Pesquisadora, Fundação Zoobotânica de Belo Horizonte, Departamento Jardim Botânico, Belo Horizonte, MG, Brasil; 2. Bacharel em Química, Professora, Doutora, Universidade Federal de São João del-Rei -UFSJ, Campus Sete Lagoas, Sete Lagoas, MG, Brasil; 3. Engenheira Agrônoma, Doutora, Pesquisadora, Empresa de Pesquisa Agropecuária de Minas Gerais, EPAMIG, Unidade Regional Centro Oeste - URCO - Prudente de Morais, MG, Brasil; 4. Matemática, Professora, Doutora, Universidade Federal de São João del-Rei -UFSJ, Campus Sete Lagoas, Sete Lagoas, MG; 5. Engenheiro Agrônomo, Professor, Doutor, Universidade Federal de São João del-Rei -UFSJ, Campus Sete Lagoas, Sete Lagoas, MG, Brasil; 6. Engenheira Agrônoma, Professora, Doutora, Universidade Federal de São João del-Rei -UFSJ, Campus Sete Lagoas, Sete Lagoas, MG, Brasil.

\begin{abstract}
The revival of non-conventional edible plants enables important gains in nutritional, social, cultural, economic, and environmental points of view. Among them, sorrel - Rumex acetosa L. - has been deemed pleasant by consumers due to its acid taste. As we do not have a lot of phytotechnical and nutritional information about this plant, the objective was to assess the influence of different spacing sets and cattle manure dosages on their physical-chemical characteristics and bioactive compounds content with antioxidant action. Randomized blocks with four repetitions was chosen as experimental design, using a scheme of subdivided plots, with five dosages of weather-beaten cattle manure in the plots and two sets of spacing in the subplots. Data was submitted to a variance analysis with two factors (two-way ANOVA). It was not verified any significant effect $(\mathrm{P}>0.05)$ in the interaction Dosage $\mathrm{x}$ Spacing. Fertilization dosages and spacing sets did not have any effect on color and total soluble solids average contents, humidity, titratable acidity, and phenolic compounds. Increasing dosages of organic fertilizer, up to $75 \mathrm{~kg} \mathrm{ha}^{-1}$, reduced the plant's $\mathrm{pH}$; above that amount, $\mathrm{pH}$ rose. Presence of anthocyanins and vitamin $\mathrm{C}$ was not detected. The total carotenoids average content was not influenced by the manure factor, and the plant presented greater total carotenoids content in the smallest spacing. Antioxidant activity $\left[1.0 \mathrm{mg} \mathrm{mL}^{-1}\right]$, although inferior to the standards that were used (BHT, vitamin $\mathrm{C}$ and quercetin), was quite representative. A conclusion was reached that fertilizing with weather-beaten cattle manure had an effect only on $\mathrm{pH}$, and cropping spacing had an influence only on carotenoids content. Other phytochemicals and physical-chemical characteristics were not influenced in sorrel plants with different levels of fertilization and sets of spacing.
\end{abstract}

KEYWORDS: Rumex acetosa. Non-conventional vegetable. Bioactive compounds.

\section{INTRODUCTION}

Preservation of local species and varieties, as well as knowledge about neglected edible plants, in addition to contributing to maintain resilience of small-scale agricultural systems, they also help to stabilize production, minimize risks, as well as profit from available micro-environments with varieties of more suitable crops (PILLA; AMOROSO, 2009). There are several vegetable species that are not used or are underused with high nutritional qualities that often are greater than those of plants usually cropped (LADIO, 2005). Non- conventional vegetables such as purslane (Portulaca oleracea), Malabar speech (Basella rubra), green amaranth (Amaranthus viridis), lamb's ear (Stachis lanata), and sorrel (Rumex acetosa) present considerable contents of minerals and natural antioxidants such as carotenoids and phenolic compounds in their constitution, and its regular consumption is associated with benefits for human health (VIANA et. al, 2015).

Sorrel (Rumex acetosa L.), having characteristic rusticity and flavor, has been found pleasant by consumers, presents good marketing potential and can contribute to enrich human diet, 
because it presents relevant amounts of macro and micronutrients in its constitution (SILVA et al., 2013), besides natural antioxidant compounds such as phenolic and carotenoid compounds (VIANA et al., 2015). Sorrel belongs to the Poligonaceae family and is herbaceous, perennial, about $20 \mathrm{~cm} \mathrm{(8} \mathrm{in)}$ high, forming clumps with several propagules. It is usually found in the wilds in regions with mild climate in Europe and Asia; in Brazil, it is cropped from the State of Rio Grande do Sul to the State of Minas Gerais. However, it rarely blossoms in Brazilian climate conditions (PEDROSA et al. 2012; SILVEIRA et al., 2013; MADEIRA et al., 2013).

In recent years, a greater conscience about the influence of food in health and its direct reflexes in quality of life has been generating an increase on the demand for healthier food. It is also possible to see that farmers are adopting a more conscious attitude about their products' nutrient content (RODRIGUES-AMAYA et al., 2008). However, according to Miliauskas et al. (2004), there is few scientific information about the nutritional composition and the bioactive substances with health-promoting proprieties content, especially regarding plants less used in medicine and culinary.

Food's healing and preventive power have been emphatically associated with the presence of antioxidants, and sometimes correlated to bioactive substances concentrations, even if the antioxidant effect in a piece of food is clearly differentiated from its effect in health (RODRIGUEZ-AMAYA et al., 2008). According to Bernardes et al. (2011), the ingestion of food containing bioactive compounds such as carotenoids, phenolic compounds and vitamins constitutes the main form for the organism to obtain antioxidants.

Therefore, the determination of bioactive compounds in vegetables is essential to assess the source food of those compounds, add scientific knowledge about food nutritional composition and the benefits in preventing diseases and reinforcing the importance of daily consuming these products (FALLER; FIALHO, 2009).

However, it is worth highlighting that environmental conditions, fertilization, genetic factors, plant variety, among others, widely influence phytochemical content in vegetables (RAMOS et al. 2011). In addition, studies that correlate cropping practices with phytochemicals production are rare (ARBOS et al., 2010).

The development of non-conventional vegetables organic cropping technologies can increase the diversity of quality food products, contribute to population's food and nutritional safety, provide technical assistance to the producer, favor environmental conservation, encourage production and consumption of those plants.

Thus, this present study aimed to assess physical-chemical characteristics and bioactive compounds content in sorrel cropped in different sets of spacing and with different dosages of fertilization with weather-beaten cattle manure.

\section{MATERIAL AND METHODS}

The experiment was carried out in EPAMIG's Fazenda Experimental Santa Rita, in the City of Prudente de Morais, State of Minas Gerais $\left(19^{\circ} 27^{\prime} 15^{\prime \prime} \mathrm{S}\right.$ and $44^{\circ} 09^{\prime} 11^{\prime \prime} \mathrm{W}$ and altitude of $732 \mathrm{~m}$ [0.45 miles]). The region is classified as Aw according to Köppen (Tropical Wet and Dry or Savanna), with a dry season from May to October and a wet one from November to April. Soil was classified as Red-Yellow Latosol, is clayey in texture and presented the following characteristics in the layer from 0 a $20 \mathrm{~cm}$ ( 0 to 8 in) deep: $\mathrm{pH}$ (water) $=6.5 ; \mathrm{Ca}^{2+}=5.0 ; \mathrm{Mg}^{2+}=0.8 ; \mathrm{Na}=0.1 ; \mathrm{Al}^{3+}$ $=0.0 ; \mathrm{H}+\mathrm{Al}=2.0, \mathrm{SB}=6.5 ; \mathrm{t}=6.5 ; \mathrm{T}=8.5$ expressed in $\mathrm{cmol}_{\mathrm{c}} \mathrm{dm}^{-3}, \mathrm{~V}=76 ; \mathrm{m}=0$ expressed in $\% ; \mathrm{P}=8.1 \mathrm{mg} \mathrm{dm}^{-3}$ (Mehlich 1); $\mathrm{K}=225 \mathrm{mg} \mathrm{dm}^{-3}$, organic matter $=2.7 \mathrm{dag} \mathrm{kg}^{-1} ; \mathrm{B}=0.4 ; \mathrm{Cu}=1.0 ; \mathrm{Fe}$ $=18.9 ; \mathrm{Mn}=31.6 ; \mathrm{Zn}=2.5$ expressed in $\mathrm{mg} . \mathrm{dm}^{-3}$; Prem $=15.5 \mathrm{mg} \cdot \mathrm{L}^{-1}$ and $\mathrm{CE}=0.3 \mathrm{dS} \mathrm{m}^{-1}$.

Weather-beaten cattle samples, dried in a greenhouse at $75^{\circ} \mathrm{C}\left(167^{\circ} \mathrm{F}\right)$, presented the following chemical characteristics: $\mathrm{pH}$ (water) = 6.9; $\mathrm{N}=1.72 ; \mathrm{P}=0.84 ; \mathrm{K}=1.44 ; \mathrm{Ca}=2.03 ; \mathrm{Mg}=$ $0.52 ; \mathrm{S}=0.69$, organic carbon $=10.61$ and $\mathrm{Na}=$ 0.036 expressed in \%; $\mathrm{Fe}=29,514 ; \mathrm{Cu}=43 ; \mathrm{Zn}=$ 204; $\mathrm{B}=8.2$ and $\mathrm{Mn}=517$, expressed in ppm; $\mathrm{C} / \mathrm{N}$ $=6.16$; air humidity contents $=12.22 \%$, in a greenhouse at $75^{\circ} \mathrm{C}\left(167^{\circ} \mathrm{F}\right)=21.52 \%$ and density $=0.719 \mathrm{~g} \mathrm{~cm}^{-3}$.

This study assessed sorrel (Rumex acetosa L.) type I, according to Silva et al. (2013), whose exsiccated sample is deposited in EPAMIG's herbarium with the following registration: PAMG 57029. Matrixes that were cropped in the nonconventional vegetables center in EPAMIG's Fazenda Experimental Santa Rita in the City of Prudente de Morais were used to produce seedlings. Plastic bags measuring approximately $20 \mathrm{~cm} \mathrm{x} 10$ $\mathrm{cm}$ (8 in $\mathrm{x} 4$ in) were used, with a substrate composed by the mixture of ravine soil and weatherbeaten cattle manure in a 1:1 proportion and placed in a vegetation housing.

Randomized blocks with four repetitions was chosen as experimental design, with a scheme of subdivided plots. The plots consisted of five 
levels of weather-beaten cattle manure fertilization factor translated into dosages of weather-beaten cattle manure $\left(0,25,50,75\right.$, and $\left.100 \mathrm{t} \mathrm{ha}^{-1}\right)$, and subplots were two levels of spacing factor $(2 \mathrm{~cm} \mathrm{x}$ $25 \mathrm{~cm}$ and $30 \mathrm{~cm} \times 30 \mathrm{~cm} / 0.8$ in $\times 9.4$ in and 11.8 in $\mathrm{x} 11.8$ in).

In the plots, which consisted of seedbeds of $1.20 \mathrm{~m} \mathrm{x} 4.00 \mathrm{~m}(3.9 \mathrm{ft} \times 13.1 \mathrm{ft})$ and $0.20 \mathrm{~m}(0.6 \mathrm{ft})$ high, weather-beaten cattle manure dosages were distributed, being $2 / 3$ of the dosage applied five days before transplantation and $1 / 3$ of it applied in coverage, 20 days after planting the seedlings. In the subplots, with an area of $2.4 \mathrm{~m}^{2}\left(25.8 \mathrm{ft}^{2}\right), 24$ seedlings were planted, distributed in four lines of six plants, in the respective sets of spacing. The eight central plants were considered for the composition of the useful plot.

Periodical hoeing was used as a farming practice, and it was not necessary to perform plague and disease control. Sprinkling irrigation was performed using a SANTENO I $-09 / 1 \mathrm{Kgf} \mathrm{cm}^{-2}$ hose. Plants were cut at $3 \mathrm{~cm}$ (1.1 in) from soil level, on the 57th day after transplanting, when they reached a point of harvesting.

Leaves were harvested by chance and transported under refrigeration to Federal University of São João del-Rei's (UFSJ) Sete Lagoas Campus, where analysis was carried out.

After verifying the assumptions of normality and homogeneity through Shapiro-Wilk and Levene tests, dada collected was submitted to a variance analysis with two factors (two-way ANOVA), according to the statistical model for randomized blocks with a scheme of subdivided plots.

Facing the statistical significance of the fertilization factor, a regression study was performed on tendency analysis between dosages of organic fertilizer. For the spacing factor, the amount of statistic F was considered; and to compare treatment averages against control groups, Tukey test was used. In every analysis, a nominal level of $5 \%$ of significance was adopted. The statistical analysis was carried out using R Software (R CORE TEAM, 2014).

These were assessed during the experiment: physical-chemical characteristics, bioactive compounds and antioxidant activity, which will be described as it follows.

\section{Physical-chemical assessment}

The instrumental color was measured in three different points of full leaves' abaxial surfaces, with the aid of a Konica Minolta colorimeter, model
CR 410with D65/10 illumination pattern, to read parameters $\mathrm{L}^{*}, \mathrm{a}^{*}$, and $\mathrm{b}^{*}$.

Total soluble solids content was determined through a direct reading from the filtered portion, obtained from grounded leaves, placed on digital Reichert model R2mini refractometer prism, with automatic temperature compensation (AOAC, 2012). Results were expressed in ${ }^{\circ}$ Brix.

Humidity was obtained from the difference between initial and final mass of the sample dried in a sterilization greenhouse and drying process at $105^{\circ}$ $\mathrm{C}\left(221^{\circ} \mathrm{F}\right)$ until constant weight (AOAC, 2012).

$\mathrm{pH}$ was determined by potentiometry (AOAC, 2012), with the aid of a digital pH meter, through direct immersion of the electrode in the homogenized in natura samples that were added 5 $\mathrm{mL}(0.18 \mathrm{oz})$ of deionized water.

Titratable acidity was determined by titulometry using $\mathrm{NaOH} 0.01 \mathrm{~N}$ as solution and phenolphthalein as indicator, according to the methodology described in AOAC (2012). Results were expressed in percentage of citric acid.

\section{Assessment of bioactive compounds}

Total carotenoids were extracted with acetone p.a. and quantified by spectophotometry at $450 \mathrm{~nm}$ (RODRIGUEZ-AMAYA, 1999). Results were expressed in $\mu \mathrm{g}$ of carotenoids by 100 grams $(0.22 \mathrm{lb})$ of fresh mass.

Total phenolic compounds content in methanolic extracts of the plants was determined by Folin-Denis method, according to AOAC (2012). Results were expressed in $\mathrm{mg}$ of gallic acid equivalents (GAE) by 100 grams $(0.22 \mathrm{lb})$ of dry mass.

Anthocyanins were assessed through differential $\mathrm{pH}$ method, as described by Giusti \& Wrolstad, (2001). Absorbance was calculated from the

equation

$A=(A \lambda 510-A \lambda 700) p H 1-(A \lambda 510-A \lambda 700) p H 4.5$ , where $A \lambda 510=$ absorbance in wavelength of 510 $\mathrm{nm}, \mathrm{A} \lambda 700=$ absorbance in wavelength of $700 \mathrm{~nm}$, $(\mathrm{A} \lambda 510-\mathrm{A} \lambda 700) \mathrm{pH} 1=$ difference of absorbance amounts read in the solution $\mathrm{pH} 1.0$ and (A $\lambda 510-$ A 2700$) \mathrm{pH} 4.5=$ difference of absorbance amounts read in the solution $\mathrm{pH} 4.5$.

Concentration of monomeric pigments in the extract was represented in cyanidin-3-glycoside and calculated using the equation $\mathrm{MA}=$ $($ AxMWxDFx 102 $) /\left(\begin{array}{lll}\varepsilon & \mathrm{x}\end{array}\right)$, where $\mathrm{MA}=$ Monomeric anthocyanin (mg $\left.100 \mathrm{~g}^{-1}\right), \quad \mathrm{A}=$ absorbance difference calculated by previous equation, $\mathrm{MW}=$ molecular weight of cyanidin-3glycoside $(=449.2), \mathrm{DF}=$ dilution factor, $\varepsilon=$ molar 
absorptivity $=269,000, \mathrm{~L}=$ optical path $=1 \mathrm{~cm}$ (0.03 ft).

Ascorbic acid content was assessed by highperformance liquid chromatography (HPLC), in a SHIMADZU chromatographer equipped with UVVIS detector, involving the following conditions: $\mathrm{C}$ 18 column (ID $4.6 \mathrm{~mm} \times 150 \mathrm{~mm} / 0.02 \mathrm{ft} \times 0.49 \mathrm{ft}$ ), loop of 20 microliters, wavelength of $254 \mathrm{~nm}$, flow of $1 \mathrm{~mL} \mathrm{~min}^{-1}$. The mobile phase was prepared from cetyltrimethylammonium bromide $\left(5 \mathrm{mmol} \mathrm{L}^{-1}\right)$ and monobasic potassium phosphate $\left(50 \mathrm{mmol} \mathrm{L}^{-1}\right) 1: 1$, according to the technique described by Benlloch et al. (1993).

\section{Assessment of antioxidant activity}

Methanolic extract's antioxidant activity was determined by the DPPH method, using as positive control BHT, vitamin $\mathrm{C}$ and quercetin. This technique consists of adding $1 \mathrm{~mL}(0.04 \mathrm{oz})$ of the extract in concentrations which vary from $0.1-1,000$ $\mu \mathrm{g} \mathrm{mL}^{-1}$ to $1 \mathrm{~mL}(0.04 \mathrm{oz})$ of a DPPH methanolic solution $(0.1 \mathrm{mM})$. This reaction was processed within 1 hour at room temperature. DPPH absorption was immediately verifiedat $515 \mathrm{~nm}$ in a FEMTO ${ }^{\circledR} 700 \mathrm{~S}$ spectophotometer. All of the experiments were carried out in triplicate. The capacity to kidnap free radicals was expressed as radical oxidation percentage of inhibition and calculated by the equation \% Inhibition $=100 \mathrm{x}$
[(ADPPH -Aextr)/ADPPH], where ADPPH is the absorbance of DPPH solution and AExtr is the absorbance of the sample in solution (ROESLER, et al., 2007). The results were expressed in $\%$ and compared to reference patterns.

\section{RESULTS AND DISCUSSION}

The variance analysis did not reveal any significant effect $(p>0.05)$ in the interaction Fertilization $x$ Spacing, which indicates that these factors act independently on every assessed characteristic. Thus, the effects of the main (Fertilization) and secondary (Spacing) factors were separately studied.

The dosages of fertilization and sets of spacing that were used did not have any effect on sorrel's coloration, whose averages of the amounts were equivalent to: $L^{*}=48.50, a^{*}=-16.91$ and $b^{*}$ $=28.43$ (Table 1). It was verified that the amounts obtained were very close to those found by other authors for sorrel type I, such as those observed by Silva et al. (2013): $\mathrm{L}^{*}=47.12 ; \mathrm{a}^{*}=-17.67$ and $\mathrm{b}^{*}=$ 30.95 , even though plants were cropped in different time, place and system. Viana et al. (2014) obtained the amounts $\mathrm{L}^{*}=43.13, \mathrm{a}^{*}=-16.45, \mathrm{~b}^{*}=25.95$ immediately after harvest in a refrigerate storage study.

Table 1. Average content of $\mathrm{L}^{*}$ (luminosity), $\mathrm{a}^{*}$ and $\mathrm{b}^{*}$ (chromaticity), total soluble solids TSS $\left({ }^{\circ} \mathrm{Brix}\right.$ ), Humidity ( $\mathrm{H}, \%)$; $\mathrm{pH}$; Titratable acidity (TA, g citric acid/100 g fresh mass), Total Carotenoids (TC, $\mu \mathrm{g}$ total carotenoids/100 $\mathrm{g}$ fresh mass), Total Phenols (TP, mg total phenols/100 $\mathrm{g}$ dry mass), Antioxidant Activity from the extract in a $1.0 \mathrm{mg} \cdot \mathrm{mL}^{-1}$ concentration (AA, \%).

\begin{tabular}{lllllllllll}
\hline Sorrel & $\mathrm{L}^{*}$ & $\mathrm{a}^{*}$ & $\mathrm{~b}^{*}$ & $\mathrm{H}$ & $\mathrm{pH}$ & $\mathrm{TSS}$ & $\mathrm{TA}$ & $\mathrm{TC}$ & $\mathrm{TP}$ & $\mathrm{AA}$ \\
\hline Average & 48.50 & -16.91 & 28.43 & 82.70 & 3.11 & 3.54 & 1.22 & $5,205.00$ & 870.03 & 61.70 \\
CV 1(\%) & 3.55 & 2.89 & 4.06 & 7.38 & 4.25 & 13.78 & 14.80 & 4.76 & 16.81 & 17.42 \\
CV 2(\%) & 1.93 & 3.40 & 4.60 & 8.84 & 4.16 & 14.88 & 13.59 & 3.36 & 25.05 & 15.22 \\
\hline \multicolumn{7}{l}{ GAE = gallic acid equivalent. $\mathrm{L}^{*}=0$ (black) to 100 (white); $\mathrm{a}^{*}=-80$ (green) to +100 (red); $\mathrm{b}^{*}=-50$ (blue) to + 70 (yellow) }
\end{tabular}

The average content of total soluble solids, humidity and titratable acidity did not present significant differences $(p>0.05)$, according to what was presented in Table 1, which indicates that fertilization and spacing factors, in the assessed conditions, did not interfere on those characteristics of the plant. Sorrel leaves' acidity, which is an important characteristic of this non-conventional vegetable, in this study presented an average of 1.22 $\mathrm{g}$ (0.04 ounce) of citric acid/100 $\mathrm{g}$ of fresh matter (Table 1), an amount greatly lot superior to that reported by Silva et al. (2013) for sorrel from EPAMIG-Prudente de Morais-MG's nonconventional vegetables center $(0.11 \mathrm{~g}$ of citric acid/100 $\mathrm{g}$ of fresh matter) and by Viana et al. (2014) for sorrel from Sete Lagoas (0.81 g of citric $\mathrm{acid} / 100 \mathrm{~g}$ of fresh matter). Acidity in vegetables is attributed especially to organic acids that are found dissolved in cells vacuoles and it is a quality attribute that is related to aroma and taste of food (CHITARRA; CHITARRA, 2005).

It was verified a significant effect $(\mathrm{P}=0.05)$ in the fertilization factor for the variable $\mathrm{pH}$, indicating that this sorrel characteristic responds to the application of different fertilization dosages. An average amount of 3.11 for $\mathrm{pH}$ was observed, but a decrease on the $\mathrm{pH}$ of the plant was verified with the input of weather-beaten cattle manure up to the 
dosage of $75 \mathrm{~kg} \mathrm{ha}^{-1}$ when compared to the witness. Above that dosage, there was an increase on the $\mathrm{pH}$ amount (Figure 1).

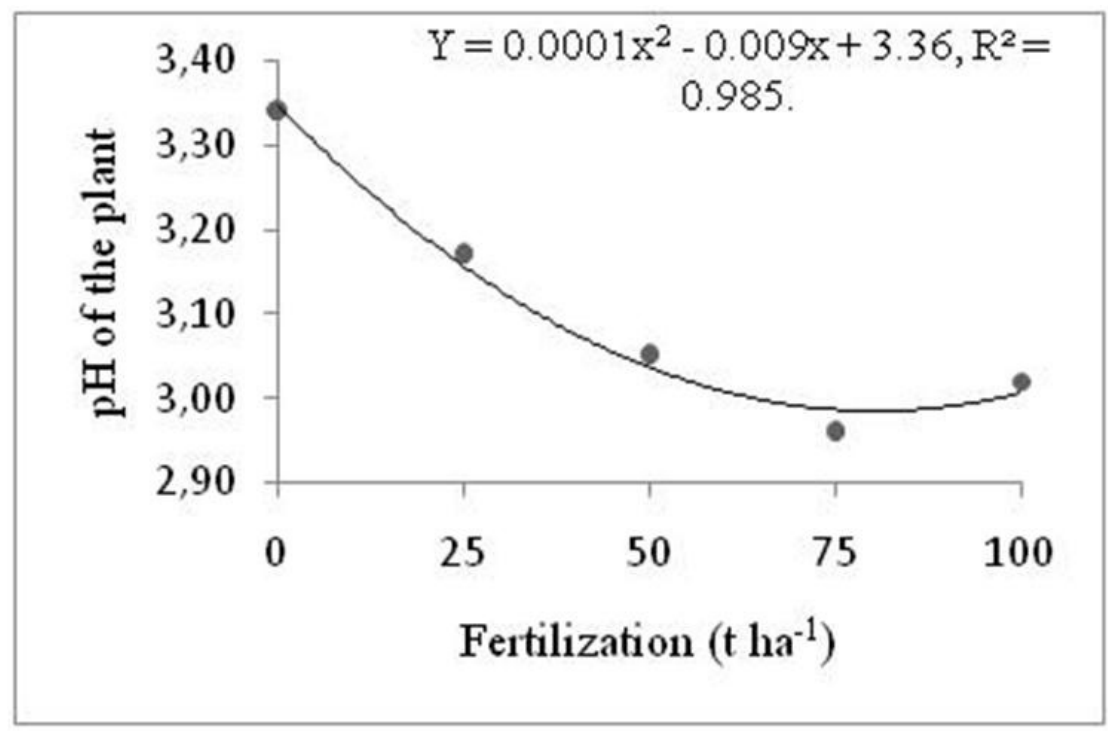

Figure 1. Regression model adjusted for $\mathrm{pH}$ of the plant, according to the application of weather-beaten cattle manure dosages $\left(\mathrm{t} \mathrm{ha}^{-1}\right)$.

The increasing application of weatherbeaten cattle manure probably had an influence on the quantity and quality of the nutrients absorbed by the plant, which interfered in its $\mathrm{pH}$. The tendency of the $\mathrm{pH}$ of the plant to increase in dosages above $75 \mathrm{tha}^{-1}$ may be related to soil reactions, considering that, in the soil, the increase or reduction of $\mathrm{pH}$, due to application of organic matter, depends on the predominance of the processes that consume or release $\mathrm{H}^{+}$(SILVA; MENDONÇA, 2007). That interferes in the availability of the nutrients to plants, such as those of $\mathrm{Cu}, \mathrm{Fe}, \mathrm{Mn}$ and $\mathrm{Zn}$ cations, which are converted into insoluble forms with the elevation of the $\mathrm{pH}$ of the soil (RESENDE, 2009). $\mathrm{PH}$ amounts observed in this study are in accordance with those detected in sorrel leaves in other studies - 2.98 and 3.22 (SILVA et al., 2013 and VIANA et al., 2014), respectively.

The factors of fertilization and spacing did not present any significant effect $(\mathrm{p}>0.05)$ on phenolic compounds. The average content of total phenols found was equivalent to 840.03 or 870.03 mg. GAE $100 \mathrm{~g}^{-1}$ dry mass (Table 1), an amount inferior to that related by Vieira et al. (2010) to Barbados gooseberry $\left(1,693.33 \mathrm{mg}\right.$ GAE $100 \mathrm{~g}^{-1}$ dry mass), a species that also integrates the list of nonconventional vegetables, and to contents quantified by Asolini et al. (2006) in yerba mate $(14,500 \mathrm{mg}$ GAE g ${ }^{-1}$ dry leaf), rosemary $\left(8,000 \mathrm{mg}\right.$ GAE $100 \mathrm{~g}^{-1}$ dry leaf) and broadleaf plantain (6,500 mg GAE 100 $\mathrm{g}^{-1}$ dry leaf), species considered sources of phenolic compounds. It is worth highlighting that those authors used Folin-Ciocalteau spectophotometric method. The average content of total phenols found in sorrel becomes a lot more expressive when compared to the amounts that Arbos et al. (2010), who also used Folin-Ciocalteau reagent, obtained in vegetables, such as organic arugula $(126.84 \mathrm{mg}$ GAE.100 $\mathrm{g}^{-1}$ ), organic lettuce (108.72 mg GAE.100 $\left.\mathrm{g}^{-1}\right)$ and organic common chicory $(92.15 \mathrm{mg}$ GAE. $\left.100 \mathrm{~g}^{-1}\right)$.

The presence of anthocyanins and vitamin $\mathrm{C}$ was not detected in sorrel leaves assessed in this present study. Viana et al. (2015) also reported the absence of vitamin $\mathrm{C}$ in sorrel type I cropped in the Non-Conventional Vegetables Center (EPAMIGPrudente de Morais-MG). However, they reported the presence of the same in leaves of sorrel type II at the concentration of $72.45 \mathrm{mg}$ of vitamin $\mathrm{C} / \mathrm{g}$ of leaf in dry basis. Ascorbic acid or vitamin $\mathrm{C}$ is present in several fruits and vegetables, such as broccoli, cauliflower, spinach, pepper, bell pepper, cabbage, among others; and many pre- and post-harvest factors - cultivar used, climate conditions, planting practices, etc.- have an influence on its concentration (CARVALHO et al., 2006).

The average content of total carotenoids was equivalent to 5,200 $\mu \mathrm{g} 100 \mathrm{~g}^{-1}$ fresh mass (Table 1), an amount inferior to those found by Vieira et al. (2015) for sorrel type I $\left(9,464.00 \mu \mathrm{g} 100 \mathrm{~g}^{-1}\right.$ fresh mass) and for sorrel type II $\left(8,385.00 \mu \mathrm{g} 100 \mathrm{~g}^{-1}\right.$ fresh mass). These amounts are comparable to those detected on other non-conventional vegetables such as sow thistle $\left(5,440 \mu \mathrm{g} 100 \mathrm{~g}^{-1}\right)$, Barbados 
gooseberry $\left(4,830 \mu \mathrm{g} \quad 100 \mathrm{~g}^{-1}\right)$ and arrow leaf elephant year $\left(3,170 \mu \mathrm{g} 100 \mathrm{~g}^{-1}\right)$, which stand out as promising sources of lutein, and on conventional vegetables like cauliflower $\left(7,890 \mu \mathrm{g} \quad 100 \mathrm{~g}^{-1}\right)$, arugula $\left(7,180 \mu \mathrm{g} 100 \mathrm{~g}^{-1}\right)$, mustard plant $(4,300 \mu \mathrm{g}$ $\left.100 \mathrm{~g}^{-1}\right)$, chard $\left(4,150 \mu \mathrm{g} 100 \mathrm{~g}^{-1}\right)$, and spinach $(3,530$ $\mu \mathrm{g} 100 \mathrm{~g}^{-1}$ ), considering fresh mass (NACHTIGALL et al., 2007).

Green vegetables have a defined qualitative profile, having lutein, $\beta$-carotene, violaxanthin and neoxanthin as main carotenoids (RODRIGUEZAMAYA et al., 2008). These authors consider to be sources rich in carotenoid food that contains important-for-health carotenoids greater than 2,000 $\mu \mathrm{g} 100 \mathrm{~g}^{-1}$. In a previous study, despite carotenoid content being expressive, it was detected the presence of $781.00 \mu \mathrm{g}$ of $\beta$-carotene. $100 \mathrm{~g}^{-1}$ fresh matter (VIANA et al., 2015).

A significant difference was revealed about total carotenoids content $(\mathrm{P}=0.0057)$ according to the spacing factor, presenting greater average content $\left(5,294.23 \mu \mathrm{g}\right.$ of carotenoids. $100 \mathrm{~g}^{-1}$ fresh mass) in the smallest spacing $(25 \mathrm{~cm} / 9.8 \mathrm{in})$.

Regarding the capacity to kidnap DPPH free radical from sorrel methanolic extracts, it was verified that antioxidant action was detected only when assessed on the greatest concentration (1.0 mg.mL $\left.{ }^{-1}\right)$; this was not observed on the smallest concentrations $\left(0.1 \mathrm{mg} \cdot \mathrm{mL}^{-1}\right.$ and $\left.0.01 \mathrm{mg} \cdot \mathrm{mL}^{-1}\right)$, and there was a significant difference $(\mathrm{P}<0.05)$ in relation to fertilization dosages $(\mathrm{P}<0.0001)$.

The average amount of antioxidant activity in the dosages of 25 and $50 \mathrm{t} \mathrm{ha}^{-1}$ of weather-beaten cattle manure was equal to $73.0 \%$ (Table 2), and it was the one closest to the average amounts presented by BHT (butylhydroxytoluene) patterns, vitamin $\mathrm{C}$ and quercetin equal to $83.85,91.72$ and $86.61 \%$, respectively.

Table 2. Antioxidant capacity of methanolic extracts of sorrel leaves and BHT (butylhydroxytoluene), vitamin $\mathrm{C}$, and quercetin patterns. Results expressed in $\%$.

\begin{tabular}{|c|c|}
\hline $\begin{array}{l}\text { Weather-beaten cattle manure dosages } \\
\left(\mathrm{t} \mathrm{ha}^{-1}\right)\end{array}$ & $\begin{array}{l}\text { Antioxidant activity } \\
\left(\mathrm{mg} \mathrm{mL}^{-1}\right)\end{array}$ \\
\hline 0 & $63.00^{c}$ \\
\hline 25 & $74.29^{\mathrm{b}}$ \\
\hline 50 & $71.63^{b}$ \\
\hline 75 & $48.31^{\mathrm{d}}$ \\
\hline 100 & $51.29^{\mathrm{d}}$ \\
\hline BHT pattern & $83.85^{\mathrm{a}}$ \\
\hline Vitamin C pattern & $91.72^{\mathrm{a}}$ \\
\hline Quercetin pattern & $86.61^{\mathrm{a}}$ \\
\hline
\end{tabular}

* Significantly different from control groups by Tukey test $(\mathrm{p}<0.05)$.

There was a significant variation between the amounts of antioxidant activity in relation to the fertilization dosages and reference patterns that were assessed. There was not a significant difference between the dosages of 25 and 50, and they showed an antioxidant capacity superior to that of the control group (without application of weatherbeaten cattle manure) and to those of the plants that received dosages of 100 and $75\left(\mathrm{t} \mathrm{ha}^{-1}\right)$ of weatherbeaten cattle manure.

Similar results were described by Arbos and assistants (2010), who detected an antioxidant capacity of $72.3,77.2$ and $77.3 \%$ at a $1.0 \mathrm{mg} \mathrm{mL}^{-1}$ concentration for organic-produced lettuce, common chicory and arugula, respectively. These amounts were superior to those obtained in conventional cropping - 62.7, 66.6 and $70.1 \%$ for lettuce, common chicory and arugula, respectively. Therefore, results of organic lettuce produced with cattle-manure-based bio-fertilizers were the closest ones to sorrel samples when cropped with 25 and 50 $\mathrm{t} \mathrm{ha}^{-1}$ of weather-beaten cattle manure.

Antioxidants have several modes of action, and the different methods used to determine these activities are performed under different conditions (RODRIGUES-AMAYA et al., 2008). There was no correlation between carotenoids (correlation coefficient: $-0.0737 ; \mathrm{P}=0.604)$ nor between phenolic compounds (correlation coefficient: 0.1661; $\mathrm{P}=0.3056$ ) and sorrel's antioxidant capacity. The correlation between total phenolic compounds content and antioxidant capacity is still very controversial, given that it is possible to stablish a good correlation between those two variables in several fruits and vegetables, but in some cases that correlation is low (VIZZOTTO et al., 2012). These authors attribute it to the presence of several other phytochemicals, such as carotenoids or vitamins (C and E) that may influence on the antioxidant activity. Thus, the detected antioxidant activity can 
be attributed to other compounds that were not assessed.

\section{CONCLUSIONS}

The fertilization with weather-beaten cattle manure and cropping spacing have an influence on carotenoids content, antioxidant activity and $\mathrm{pH}$.

The other sorrel phytochemicals and physical-chemical characteristics were not altered by fertilization variations with weather-beaten cattle manure and spacing, which allows us to consider that growing sorrel is viable when smaller spacing is used, with the application of small dosages of manure.

\section{ACKNOWLEDGEMENTS}

The authors thank FAPEMIG (Fundação de Amparo à Pesquisa do Estado de Minas Gerais) and CNPq (Conselho Nacional de Desenvolvimento Científico e Tecnológico) - CNPq CVT-Guayi for the financial support to the project.

RESUMO: O resgate das plantas comestíveis não convencionais possibilita ganhos importantes do ponto de vista nutricional, social, cultural, econômico e ambiental. Dentre estas, a azedinha, Rumex acetosa L. tem agradado o consumidor por seu sabor ácido. Como são poucas as informações fitotécnicas e nutricionais sobre esta planta objetivou-se avaliar a influência de diferentes espaçamentos e doses de esterco bovino em suas características físico-químicas e no teor de compostos bioativos com função antioxidante. O delineamento experimental foi em blocos casualizados com quatro repetições, no esquema de parcelas subdivididas, sendo cinco doses de esterco curtido de gado nas parcelas e dois espaçamentos nas subparcelas. Os dados foram submetidos à análise de variância com dois fatores (two-way ANOVA). Não foi constatado efeito significativo $(\mathrm{P}>0,05)$ da interação Dose $\mathrm{x}$ Espaçamento. As doses de adubação e espaçamentos não afetaram a cor e os teores médios de sólidos solúveis totais, umidade, acidez titulável e compostos fenólicos. Doses crescentes de adubo orgânico, até $75 \mathrm{~kg} \mathrm{ha}^{-1}$, reduziram o $\mathrm{pH}$ da planta, acima deste valor o $\mathrm{pH}$ elevou-se. Não foi detectada a presença de antocianinas e vitamina $\mathrm{C}$. O teor médio de carotenoides totais não foi influenciado pelo fator esterco e no menor espaçamento a planta apresentou maior teor de carotenoides totais. A atividade antioxidante [1,0 mg mL $\left.\mathrm{m}^{-1}\right]$, apesar de inferior aos padrões utilizados (BHT, vitamina $\mathrm{C}$ e quercetina), foi bastante representativa. Concluiu-se que a adubação com esterco de gado curtido afetou apenas o pH e que o espaçamento de cultivo exerceu influência apenas teor de carotenoides. Os demais fitoquímicos e características físico-químicas não foram influenciadas em plantas de azedinha com diferentes níveis de adubação e de espaçamento.

PALAVRAS CHAVES: Rumex acetosa. Hortaliça não convencional. Compostos bioativos.

\section{REFERENCES}

AOAC-ASSOCIATION OF OFFICIAL ANALYTICAL CHEMISTS. Official methods of analysis of AOAC international. 17. ed. Washington, 2002

ARBOS, K. A.; FREITAS. R. J. S.; STERTZ S. C.; DORNAS. M. F. Atividade antioxidante e teor de fenólicos totais em hortaliças orgânicas e convencionais. Ciência e Tecnologia de Alimentos, v. 30, n. 2, p. 501-506, 2010. https://doi.org/10.1590/S0101-20612010000200031

ASOLINI, P. M.; TEDESCO, A. M.; CARPES, S. T.; FERRAZ, C.; ALENCAR, S.M. Atividade antioxidante e antibacteriana dos compostos fenólicos dos extratos de plantas usadas como chás. Brazilian Journal of Food Tecnology, v. 9, n. 3, p. 209-215, 2006.

BERNARDES, N. B.;TALMA, S. V.; SAMPAIO, S. H.;NUNES, C. R.; ALMEIDA, J. A. R.; OLIVEIRA, D. B. de. Atividade Antioxidante e fenóis totais em frutas de Campos dos Goytacazes RJ. Perspectivas online, v. 1, n. 1, p. 53- 59, 2011. 
BENLLOCH R; FARRÉ R; FRIGOLLA A. A quantitative estimate of ascorbic and isoascorbic acid by high performace liquid chromatography: application to citric juices. Journa lof Liquid Chromatography, v. 16, n. 14, p. 3113-3122. https://doi.org/10.1080/10826079308019637

CARVALHO PGB; MACHADO CMM; MORETTI CL; FONSECA, MEN. 2006. Hortaliças como alimentos funcionais. Horticultura Brasileira, v. 24, p. 397-404, 1993. https://doi.org/10.1590/S0102-

05362006000400001

CHITARRA, Maria Isabel Fernandes; CHITARRA, Adimilson Bosco. Pós colheita de frutas e hortaliças: Fisiologia e manuseio. Lavras: UFLA, 2005, 785p.

FALLER, A. L. K.; FIALHO, E. Disponibilidade de polifenóis em frutas e hortaliças consumidas no Brasil. Revista Saúde Pública, v. 43, n. 2, p. 211-218, 2009. https://doi.org/10.1590/S0034-89102009005000010

GIUSTI, M. M,; WROLSTAD, R. E. Anthocyanins: characterization and measurement with UV-visible spectroscopy. In: WROLSTAD, RE. (Ed.).Current protocols in food analytical chemistry.New York: John Wiley \& Sons, 2001. (unit. F1.2) p.1-13. https://doi.org/10.1002/0471142913.faf0102s00

LADIO, A. Malezas exóticas comestibles y medicinales utilizadas enpoblacionesdel Noroeste patagónico: aspectos etnobotánicos y ecológicos. Boletín Latinoamericano y del Caribe de Plantas Medicinales y Aromáticas, v.4.n.004, p.75-80, 2005.

RESENDE, A. V. Micronutrientes na agricultura brasileira, In: LAPIDO-LOUREIRO FE; MELAMED R; FIGUEIREDO NETO J. (eds). Fertilizantes, agroindústria e sustentabilidade. Rio de Janeiro: CETEM/MCT. 2009. p 369-381.

MADEIRA, N. R.; SILVA, P. C.; BOTREL, N.; MENDONÇA, J.L. de; SILVEIRA, G.S.R.; PEDROSA, M.W. Manual de produção de hortaliças tradicionais. Brasília: EMBRAPA, 2013,156p.

MILIAUSKAS, G.;VENSKUTNISA, P.R.; BEEK, .TA.V. Screening of radical scavenging activity of some medicinal and aromatic plant extracts, Food Chemistry, v. 85, n. 2, p. 231-237. 2004.

https://doi.org/10.1016/j.foodchem.2003.05.007

NACHTIGALL, A.M.; STRINGHETA, P.C.; FIDELIS, P.C.; NACHTIGALL, F.M. Determinação do teor de luteína em hortaliças. Boletim do Centro de Pesquisa de Processamento de Alimentos, v.25, n. 2, p. 181192, 2007. https://doi.org/10.5380/cep.v25i2.5205

PEDROSA, M. W.; MASCARENHAS, M. H. T.; MAGALHÃES, K. S.; SILVÉRIO, T. T.; SILVA, A. F.; SANTOS, I. C.; SILVA, S.; SEDIYAMA, M. A. N.; FONSECA, M. C. M.; SILVEIRA, G. S. R.; OLIVEIRA, F. M.; CARVALHO, E. R. O.; PUIATTI, M.;MADEIRA, N. R.; BORTOLINI, L. O. F. Hortaliças não convencionais. 2012. Belo Horizonte: EPAMIG. 22p.

PILLA, M. A. C.; AMOROSO, M. A. M. O conhecimento sobre os recursos vegetais alimentares em bairros rurais no Vale do Paraíba, SP, Brasil. Acta Botânica Brasílica, v. 23, n.4, p.1190-1201, 2009.

https://doi.org/10.1590/S0102-33062009000400030

R CORE TEAM. R: a language and environment for statistical computing. Vienna, Austria: R Foundation for Statistical Computing. 2014. Disponível em: https://www.r-project.org/

RAMOS, D. D.; VIEIRA, M. C.; FORMAGIO, A. S. N. CARDOSO, C.A.L.; RAMOS, D.D.; CARNEVALI, T.O. Atividade antioxidante de Hibiscus sabdariffaL. em função do espaçamento entre plantas e da adubação orgânica. Ciência Rural, v. 41, n.8, p. 1331-1336. 2011. https://doi.org/10.1590/S0103-84782011005000107

RODRIGUES-AMAYA, D.B. A guide to carotenoids analyses in foods. Washington: ILSI PRESS. 1999, $119 \mathrm{p}$. 
RODRIGUES-AMAYA, D. B.; KIMURA, M.; AMAYA-FARFAN, J. Fontes brasileiras de carotenoides: tabela brasileira de composição de carotenoides em alimentos. Brasilia: MMA/SBF. 2008, 100p.

ROESLER R; MALTA LG; CARRASCO LC; HOLANDA RB; SOUSA CAS; PASTORE GM. Atividade Antioxidante de frutas do cerrado. Ciência Tecnologia Alimentos, v. 27, n.1, p. 53-60, 2007.

https://doi.org/10.1590/S0101-20612007000100010

SILVA EC; CARLOS LA; ARAÚJO AP; FERRAZ LCL; PEDROSA MW; SILVA LS. Characterization of two types of azedinha in the region of Sete Lagoas, Brazil. Horticultura Brasileira, v. 31, p. 328-331, 2013. https://doi.org/10.1590/S0102-05362013000200025

SILVA, I.R.; MENDONÇA, E.S. Matéria Orgânica do Solo. In: NOVAIS RF; ALVAREZ V VH; BARROS NF de; FONTES RLF; CANTARUTTI RB; NEVES JCL (eds). 2007. Fertilidade do Solo. Viçosa: Sociedade Brasileira de Ciência do Solo. p. 275-374.

SILVEIRA, G.S.R.; MADEIRA, N.R.; BORTOLINI, L.O.F.; OLIVEIRA, F.M.; SANTOS, R.L.B.; SOUB, M.C.R.; MASCARENHAS, M.H.T.; PEDROSA, M.W.; MARZALL, K.; PUIATTI, M.; CARVALHO, E.R.; HOMEM, T.G.; ROCHA, M.G.; CARVALHO, S.P.; FERREIRA, S.M.; MATRANGOLO, W.J.R.;

ALBERNAZ, W,; MENDONCA, J.L. Manual de hortaliças não convencionais. Brasília: MAPA, 2013. 99p.

VIANA, M.M.S.; TORRES, M.P.; CARLOS, L.A.; SILVA, E.C. Retenção de carotenoides em azedinha minimamente processada. Magistra, v. 26, p. 2303-2307, 2014.

VIANA, M. M. S. ; ALMEIDA-CARLOS, L. ; SILVA, E.C. ; PEREIRA, S. M. F. ; OLIVEIRA, D.B. ; ASSIS, M. L. V. Composição fitoquímica e potencial antioxidante de hortaliças não convencionais. Horticultura Brasileira, v. 33, n. 4, p. 504-509,2015. https://doi.org/10.1590/S0102-053620150000400016

VIEIRA, D. A; SANTOS, O.S.; HAMINIUK, C.W.I.; PLATA-OVIEDO, M.S.V. Avaliação da atividade antioxidante das folhas de acerola, guabiroba e ora-pro-nobis. Revista Brasileira de Pesquisa em Alimentos, v. 1, n. 2, p. 129-134, 2010. https://doi.org/10.14685/rebrapa.v1i2.29

VIZZOTTO, M.; RASEIRA, M. C. B.; PEREIRA, M. C.; FETTER, M. R. Teor de compostos fenólicos e atividade antioxidante em diferentes genótipos de amoreira-preta (Rubussp.) Revista Brasileira de Fruticultura, v. 34, n. 3, p. 853-858, 2012. https://doi.org/10.1590/S0100-29452012000300027 